\title{
Makara Human Behavior Studies in Asia
}

Volume 15 | Number 1

Article 5

6-1-2011

\section{Evaluasi Program Corporate Social Responsibility dan Community Development pada Industri Tambang dan Migas}

Dody Prayogo

Departemen Sosiologi, Fakultas IImu Sosial dan IImu Politik, Universitas Indonesia, Depok 16424, Indonesia, dodypo@yahoo.com

Follow this and additional works at: https://scholarhub.ui.ac.id/hubsasia

\section{Recommended Citation}

Prayogo, D. (2011). Evaluasi Program Corporate Social Responsibility dan Community Development pada Industri Tambang dan Migas. Makara Human Behavior Studies in Asia, 15(1), 43-58. https://doi.org/ 10.7454/mssh.v15i1.893

This Original Article is brought to you for free and open access by UI Scholars Hub. It has been accepted for inclusion in Makara Human Behavior Studies in Asia by an authorized editor of UI Scholars Hub. 


\title{
EVALUASI PROGRAM CORPORATE SOCIAL RESPONSIBILITY DAN COMMUNITY DEVELOPMENT PADA INDUSTRI TAMBANG DAN MIGAS
}

\author{
Dody Prayogo
}

Departemen Sosiologi, Fakultas Ilmu Sosial dan Ilmu Politik, Universitas Indonesia, Depok 16424, Indonesia

E-mail: dodypo@yahoo.com

\begin{abstract}
Abstrak
Program corporate social responsibility (CSR) dan community development (CD) telah menjadi kegiatan wajib bagi semua korporasi setelah disahkannya UU No. 40 Tahun 2007 tentang Perseroan Terbatas. Khusus bagi industri tambang dan migas, program ini memiliki posisi strategis guna membangun relasi resiprokal antara korporasi dengan pemangku kepentingan (stakeholder)-nya. Berhasil atau gagalnya program ini dapat turut menentukan "keabsahan sosial" korporasi. Untuk itu diperlukan evaluasi agar dapat menunjukkan kelebihan dan kekurangan program CSR dan CD yang telah dilakukan. Evaluasi ini sangat penting dilakukan untuk membangun dan menjamin relasi yang baik antara korporasi dengan pemangku kepentingan-nya. Untuk itu, artikel ini memaparkan hal-hal pokok dalam evaluasi program, berkenaan dengan apa (definisi) dan bagaimana (metode) evaluasi program CSR dan CD harus dilakukan, serta bagaimana implikasi (signifikansi) hasil evaluasi secara bisnis, social, dan legal.
\end{abstract}

\section{Evaluation of Corporate Social Responsibility and Community Development Programs in Mining and Oil Industries}

\begin{abstract}
Corporate social responsibility (CSR) and community development (CD) programs are now a legal requirement that should be implemented by corporations after the enactment of UU No. 40 Tahun 2007 with the limited liability company. Especially for mining and oil corporations, CSR and CD programs are strategic and significant in order to develop good and reciprocal relationships between corporation and its stakeholders. The successes or failure of the implementation of CSR and CD will directly influence "social legitimacy" of the corporation. Hence, evaluation of the program implementation is strategic in order to assess the social performance of the corporations. The result of evaluation is also important to ensure the relationships between corporation and its social stakeholders. In this regard, this article deals with the meaning of evaluation (definition), how to conduct the evaluation (method), and what is the implication (significance) of CSR and CD program, socially, legally and commercially.
\end{abstract}

Keywords: evaluation method, corporate social responsibility, community development, corporate social performance, social legitimacy

\section{Pendahuluan}

Bagaimana melihat relasi antara korporasi dengan para pemangku kepentingannya, salah satunya dapat ditinjau dari bagaimana kinerja program corporate social responsibility (CSR) atau tanggungjawab sosial korporasi dan community development (CD) atau pengembangan komunitas yang dilakukan korporasi. Tinggi rendahnya kinerja program CSR dan CD tidak mutlak menjamin baik-buruknya relasi korporasipemangku kepentingan, namun dari kinerja ini terlihat bagaimana komitmen, kebijakan dan tindakan korporasi terhadap pemangku kepentingan mereka atau khususnya terhadap komunitas terdekat (Carrol, 1999; Stone, 2001). Secara teknis, evaluasi atas kinerja program yang telah diimplementasikan merupakan sebuah keharusan manajemen guna melihat seberapa tepat tujuan yang akan dicapai dan seberapa besar capaian yang telah dihasilkan sebagai luaran ataupun hasil dari program (Buchholtz, Allen, \& Matthew 1999, Murray, 2004; Warhurst, 2001). Secara bisnis, hasil evaluasi program dapat digunakan sebagai salah satu sajian obyektif tentang social performance korporasi, yang kemudian menjadi sangat bermanfaat untuk meningkatkan 
corporate image dan bahan pertimbangan bagi calon investor dalam menanamkan modalnya (Orlitzky \& John, 2001). Secara sosial, kinerja program CSR dan CD pada gilirannya dapat menentukan seberapa besar social legitimacy (penerimaan sosial) para pemangku kepentingan, utamanya komunitas sekitar, atas komitmen, kehadiran dan tindakan korporasi secara umum (Prayogo, 2008c). Dukungan atau penolakan sosial terhadap kehadiran korporasi salah satunya sangat bergantung pada bagaimana komitmen dan tindakan korporasi terhadap mereka, yang secara obyektif dapat tercermin program CSR dan CD.

Khususnya Pada industri tambang dan migas, program CSR dan CD menjadi semakin penting dewasa ini sejalan dengan semakin kuatnya perhatian terhadap industri ekstraktif, baik karena alasan pelestarian lingkungan maupun alasan lain seperti HAM (Hak Asasi Manusia) serta perlindungan hak-hak ekonomi dan politik masyarakat lokal (Sharma, Pablo, \& Vredenburg 1999). Citra industri tambang yang relatif "buruk" di dalam persepsi para pegiat NGO (NonGovernment Office) khususnya lingkungan, menjadi pertimbangan penting bagaimana korporasi senantiasa berupaya memperbaiki citra mereka. Sebagai contoh, kasus strategi bisnis "brutal” perusahaan minyak Shell terhadap masyarakat kawasan di Ogoni, Nigeria, menghasilkan citra sangat buruk terhadap Shell di seluruh dunia. Bahkan Green Peace menempatkan perusahaan ini sebagai korporasi migas "terburuk" sedunia setelah salah seorang aktivis lingkungan lokal dihukum gantung oleh rejim ototiter Nigeria akibat perlawanan mereka menuntut kerusakan lingkungan yang dilakukan oleh Shell. Akibat peristiwa ini, Shell harus mengubah paradigma bisnisnya dengan membangun kembali skenario bisnis menghadapi perubahan pandangan masyarakat dunia (Davis, 2002). Relasi antara korporasi dengan pemangku kepentingan mereka kaji ulang sekaligus mereka sesuaikan dengan perubahan sosial-politik yang terjadi baik lokal maupun maupun global.

Citra korporasi dalam industri tambang dan migas berbeda dengan industri jasa, perkebunan atau manufaktur secara umum. Dilihat dari aspek lingkungan dan relasinya dengan komunitas lokal, citra industri tambang relatif "lebih buruk" dari industri lainnya (Yakoveleva, 2005). Hal demikian terjadi karena eksploitasi sumber alam dan praktek lingkungan yang dilakukan oleh industri ini banyak bertentangan dengan tujuan pelestarian lingkungan dan kepentingan ekonomi masyarakat lokal. Oleh karenanya, untuk membangun "citra baik" serta "relasi baik" dengan pemangku kepentingan mereka, maka penilaian kinerja CSR dan CD korporasi dalam industri tambang dan migas menjadi sangat penting dilakukan. Selanjutnya kinerja sosial korporasi yang baik akan meningkatkan peluang investor baru untuk menanamkan modalnya serta mengurangi resiko korporasi dalam relasi dengan pemangku kepentingan mereka. Secara lebih fokus evaluasi program ditujukan untuk memenuhi pertimbangan "sosial” dan "bisnis” tersebut, yakni relasi dengan pemangku kepentingan dan citra korporasi, sementara pertimbangan "teknis" atau manajemen hanya melengkapi dua pertimbangan sebelumnya. Dengan melaksanakan program CSR dan CD secara baik, maka resiko bisnis atas tekanan dari pemangku kepentingan sosial terhadap korporasi akan semakin rendah. Oleh sebab itu, untuk memastikan korporasi telah melaksanakan program CSR dan CD secara baik diperlukan evaluasi terhadap program tersebut.

\section{Metode Penelitian}

Artikel ini merupakan sebuah paparan tentang metode tulisan (cara kerja) dalam melakukan evaluasi program CSR dan CD, hasil pengalaman langsung dari sejumlah evaluasi yang telah penulis lakukan hasil sejumlah studi evaluasi di lapangan. Beberapa hasil studi tersebut antara lain: "Evaluasi program community development Conoco Phillips, Kecamatan Palmatak dan Terempa, Kabupaten Natuna, Kepulauan Riau” (2007), "Evaluasi Komprehensif Program Community Development Premier Oil, Kabupaten Natuna, Kepulauan Riau” (2008), "Evaluasi Program Community Development 2008-2009 Premier Oil, Kabupaten Anambas” (2010), dan "Studi Evaluasi dan Rencana Pengembangan Program Community Development Konsorsium Industri Tambang Granit, Kabupaten Karimun, Kepulauan Riau” (2010).

Dari hasil studi evaluasi lapangan tersebut kemudian dirumuskan kembali langkah-langkah kerja yang telah dilakukan, mulai dari studi pustaka, pengembangan disain studi, penetapan fokus substansi evaluasi, cara pengumpulan data, cara analisis data serta penarikan kesimpulan. Dengan demikian analisis data dilakukan terhadap hasil-hasil laporan studi di atas dengan membandingkan metode antara hasil penelitian satu dengan yang lain, dan kemudian merumuskan kembali langkah-langkah kerja keseluruhan. Analisis dilakukan bukan terhadp data hasil penelitian, melainkan langkah kerja yang telah dilakukan. Untuk itu, berikut ini dipaparkan bagaimana langkah-langkah hasil-hasil studi evaluasi tersebut.

\section{Hasil dan Pembahasan}

3.1 Evaluasi Program. Secara akademik, metode kerja evaluasi CD sama dengan riset ilmiah umumnya, hanya dalam evaluasi diberikan penekanan aspek praktis secara labih khusus. Artinya, evaluasi program lebih ditujukan untuk menilai capaian kerja serta bagaimana menyempurnakan program selanjutnya. Namun demikian, masalah objektivitas, netralitas, validitas, 
serta reliabilitas adalah sama dengan penelitian akademik karena hasil evaluasi harus obyektif agar absah digunakan sebagai dasar kebijakan program selanjutnya.

Untuk itu, dapat dipaparkan bahwa secara garis besar metode kerja dapat dibagi menjadi tiga bagian, yaitu: pertama, melakukan formulasi disain evaluasi termasuk menetapkan variabel, indikator dan ukuran serta metode pengumpulan dan analisis data. Kedua, melakukan penelitian lapangan dengan sebelumnya membuat rencana kerja, menetapkan sampel, informan, objek observasi dan data sekunder. Ketiga, memproses, menyeleksi dan merapikan data, baik data kuantitatif maupun kualitatif. Pada bagian ini juga dilakukan analisis data dan penulisan laporan.

Langkah kerja seperti ini sangat umum dilakukan dalam penelitian lapangan. Namun perbedaannya, substansi dan metode dalam evaluasi dirancang secara khusus untuk memberikan penilaian "baik-buruk" atau "berhasil-gagal" berkenaan dengan keadaan atau capaian kerja program. Oleh sebab itu, dalam proses penilaian ini sangat ditekankan pentingnya etika dan pendekatan yang terandalkan agar hasil evaluasi benarbenar.

Pengertian evaluasi (evaluation) kerap dibaurkan dengan konsep sejenis lain seperti monitoring atau appraisal. Dalam prakteknya, keseluruhan konsep tersebut memang saling berkait-erat, namun akan berbeda jika dikaitkan dengan substansi yang hendak diukur. Secara konseptual Dale (2004) membedakan konsep-konsep tersebut. Evaluasi merupakan upaya menilai keseluruhan sejumlah hasil dari sebuah kegiatan atau program pembangunan. Konsep monitoring akan lebih spesifik memfokuskan penilaian pada hal tertentu saja seperti keadaan antar waktu saat program masih dalam proses implementasi. Jika didefinisikan, evaluasi merupakan upaya bagaimana menilai capaian tertentu sebuah program atau kegiatan pembangunan, "...assessing the value of...”. Menilai hasil atau capaian kegiatan bisa berupa kegiatan proyek atau program, baik di pertengahan maupun di akhir program. Tujuan utama melakukan evaluasi adalah untuk memastikan bahwa program yang dilakukan berjalan sebagaimana rencana yang dibuat serta sesuai dengan tujuan akhir yang hendak dicapai. Karenanya, variabel utama yang perlu dinilai dalam evaluasi mengacu kepada variabel tujuan program atau proyek dan kemudian mengukurnya seberapa jauh capaian program menurut indikator tujuan dimaksud. Monitoring merupakan penilaian saat tertentu saja atas program atau proyek yang masih sedang berjalan, "frequent assessment of output or outcome..." (Dale, 2004). Monitoring merupakan penilaian berkelanjutan atas proyek atau program yang sedang berjalan, bisa setiap triwulan, semester, atau tahunan, untuk memastikan implementasi dan alokasi resource berjalan sebagaimana rencana dan jadwal. Adapun appraisal merupakan penilaian atas proposal atau usulan kegiatan, dapat berupa proyek atau program, berkenaan dengan apakah usulan tersebut layak dikerjakan baik dinilai dari input-nya maupun kemungkinan capaiannya luarannya.

3.2 Bentuk Evaluasi. Berkaitan dengan konsep evaluasi, dapat dibedakan tiga bentuk evaluasi, yakni formative evaluation, summative evaluation, dan empowerment evaluation (Dale, 2004). Evaluasi formatif (formative evaluasi) merupakan penilaian untuk meningkatkan kinerja atau kinerja program, biasanya dilakukan saat program masih atau sedang berjalan. Evaluasi seperti ini banyak dilakukan di pertengahan program, dimaksudkan untuk memastikan bahwa program berjalan sesuai rencana dan jadwal sehingga tujuan dapat tercapai tepat waktu. Evaluasi sumatif (summative evaluation) adalah evaluasi di akhir program untuk memastikan bahwa program yang dijalankan berhasil atau gagal menurut tujuan program. Penilaian seperti ini diperlukan untuk memastikan bahwa jika program yang sama diterapkan di tempat lain yang konteksnya relatif sama maka akan diperoleh tingkat keberhasilan yang sama pula. Oleh sebab itu, dalam evaluasi sumatif, penilaian dilakukan secara menyeluruh terhadap elemen perencanaan dan variabel tujuan yang hendak dicapai. Bentuk ketiga, yakni evaluasi pemberdayaan (empowerment evaluation), adalah penilaian untuk melihat tingkat keberhasilan kegiatan atau program menurut ukuran "pemberdayaan," seperti capacity building, kemampuan mengelola organisasi, peningkatan kesadaran pemanfaat serta aspek lain terkait dengan konsep pemberdayaan. Dengan tujuan program seperti ini, maka penilaian hasil program berbeda dengan bentuk evaluasi lainnya, yakni menilai seberapa besar "tingkat kemandirian" penerima jika program sepenuhnya dilaksanakan mereka.

Perbedaan bentuk-bentuk evaluasi turut ditentukan oleh bagaimana pendekatan program (CSR dan CD) yang digunakan. Karena perbedaan pendekatan program dipengaruhi oleh perspektif dan pendekatan, kepentingan serta tujuan yang hendak dicapai, maka evaluasi atas keberhasilan program harus merujuk pada aspek tersebut. Tingkat keberhasilan program menurut perspektif locality development, misalnya, akan berbeda dengan perpektif social action dan social planning (Botes and Rensburg, 2000; Gunn \& Hazel, 1991). Karena tujuan program menurut perpektif locality development adalah melakukan pembangunan dengan meningkatkan kemandirian, maka ukuran keberhasilannya adalah derajat "independency" komunitas atau masyarakat terhadap bantuan dan intervensi luar. Sementara menurut perpektif social action, tujuan program CSR dan CD adalah membuat perubahan sosial, meningkatkan posisi tawar komunitas atau masyarakat terhadap institusi lain sehingga pengukuran keberhasilan program akan ditekankan pada tingkat 
"pemberdayaan" yang dicapai oleh komunitas bersangkutan. Menurut pendekatan ini bentuk evaluasi yang kerap digunakan adalah bentuk evaluasi pemberdayaan dengan melihat bagaimana capacity building komunitas dalam melakukan pembangunan atau bahkan gerakan sosial secara mandiri.

Pada pendekatan social planning, tujuan utama yang hendak dicapai adalah memecahkan masalah tertentu dalam masyarakat, seperti masalah kemiskinan, pendidikan, kesehatan atau sejenisnya. Untuk tujuan itu maka keberhasilan program dilihat dari seberapa jauh derajat pemecahan masalah dimaksud dapat tercapai, sehingga bentuk evaluasi yang relevan digunakan adalah bentuk evaluasi formatif dan sumatif. Karena pendekatan program CSR dan CD lebih mengacu pada social planning, maka bentuk evaluasi program yang banyak dilakukan adalah bentuk formatif dan sumatif.

Evaluasi formatif dimaksudkan untuk menilai capaian program sesuai dengan rencana, sementara sumatif digunakan untuk menjamin bahwa program tersebut dapat diaplikasikan di tempat lain. Secara singkat dapat disimpulkan bahwa bentuk evaluasi yang digunakan menyesuaikan diri-baik isi maupun metodenyadengan pendekatan program yang digunakan karena masing-masing pendekatan memiliki misi dan strategi kerja yang berbeda.

Jika lebih dipertajam, bentuk evaluasi formatif dan sumatif dapat lebih diperinci dengan melihat tujuan atau capaian yang hendak dicapai dalam dokumen perencanaan. Tujuan atau capaian ini dapat dilihat pada masing-masing indikatornya. Idealnya memang tujuan dan indikator keberhasilan program tertera dalam dokumen perencanaan, namun sebagian besar program CSR dan CD tidak mencantumkan indikator keberhasilan, bahkan banyak korporasi tidak memiliki dokumen perencanaan CSR dan CD. Jika hal ini yang terjadi maka sebelum melakukan evaluasi terlebih dahulu harus dikembangkan indikator dan ukuran. Secara struktural, evaluasi keberhasilan program secara keseluruhan dapat dipilah dalam tingkatan prosesnya, yakni dari tujuan langsung yang nyata (outcome) hingga ke tingkat yang lebih tidak langsung seperti dampak (impact). Dengan kerangka ini dapat dievaluasi keadaan mulai dari tingkat intended objectives hingga ke tingkat development objectives. Pada tingkat intended (capaian), evaluasi dilakukan terhadap output atau keluaran program secara langsung, apakah keluaran sesuai dengan yang direncanakan atau tidak (Tabel 1).

Pada tingkat immediate (langsung), evaluasi dapat dilakukan terhadap perubahan yang secara langsung dan nyata dapat diidentifikasi (direct change). Pada model perencanaan direct change ini kerap disebut dengan outcome (Maignan \& Ferrell 2004). Pada tingkat effects, evaluasi dapat difokuskan pada bentuk perubahan lebih
Tabel 1. Tingkatan Perencanaan dan Indikator Evaluasi

\begin{tabular}{lc}
\hline \multicolumn{1}{c}{ Perencanaan } & Evaluasi \\
\hline Intended objectives & Outputs \\
Immediate objectives & Direct chanmge/outcomes \\
Effects objectives & Effects \\
Development objectives & Impacts \\
\hline
\end{tabular}

Sumber: Dale, 2004.

lanjut dari outcome, adakah dan seberapa besar program berpengaruh terhadap aspek atau keadaan yang lain. Akhirnya, secara keseluruhan evaluasi program dapat dilihat dari impacts, yakni dampak keseluruhan program terhadap keadaan masyarakat yang hendak dibangun. Dengan penilaian secara bertingkat seperti ini, maka dapat dilihat hingga tingkat mana keberhasilan sebuah program.

Namun kelemahan utama dari cara penilaian seperti ini adalah tidak seluruh dokumen perencanaan program menyediakan indikator, artinya indikator outputs, outcomes, effects dan impacts, harus dibangun oleh para penilai sebelum melakukan evaluasi. Jika ini yang terjadi bias dapat terjadi karena evaluator tidak selalu memahami betul "jiwa" dari perencanaan program yang dimaksud dan hanya melihat pada tujuan dan capaian akhir dari program saja. Mungkin saja terdapat "hidden agenda" yang sebenarnya ada dalam program namun tidak terungkap dalam evaluasi.

3.3 Etika Evaluasi. Metode merupakan bagian penting dalam proses evaluasi karena validitas (keabsahan) hasil evaluasi ditentukan oleh metode evaluasi ini. Namun selain metode evaluasi, integritas evaluator sebagai aktor pelaksana sangat menentukan absah-tidaknya hasil evaluasi (Denzin \& Lincoln, 2000). Terdapat beberapa prinsip penting yang perlu ditegaskan, yakni objektivitas (berdasar kenyataan) dan netralitas (tidak berpihak). Untuk mencapai objektivitas dan netralitas diperlukan integritas dari aktor pelaksana evaluasi (evaluator). Kerap operasionalisasi instrumen evaluasi dikembangkan oleh evaluator, mulai dari pengumpulan data, perapihan dan seleksi data, penyajian data, hingga penyimpulan akhir, sehingga integritas aktor sangat menentukan keseluruhan hasil evaluasi. Kesimpulan akhir evaluasi dapat berbeda jika aktor pelaksananya memiliki kepentingan atas hasil evaluasi. Oleh sebab itu, sangat disarankan pekerjaan evaluasi dilakukan oleh pihak ketiga, bukan oleh pelaksana program atau penyandang dana atau pemberi donor. Dengan posisinya sebagai pihak ketiga_-yang diasumsikan tidak memiliki kepentingan-evaluator dapat melakukan evaluasi secara netral, obyektif dan value free (bebas nilai). Lebih dari itu, hasil evaluasi akan lebih dapat diterima oleh kalangan luas jika dikerjakan oleh lembaga atau aktor yang dapat dipercaya integritasnya. Saat ini, lembaga yang kuat dan dapat dipercaya serta diterima 
oleh semua pihak (legitimasi tinggi) dalam memberikan penilaian program CSR dan CD korporasi praktis masih sangat terbatas. Karenanya dalam evaluasi program CSR dan CD—sebagaimana kerja akademik umumnya-integritas pelaksana evaluasi menentuan keabsahan dan tingkat kepercayaan pihak terkait atas hasil evaluasi keseluruhan.

Selain masalah etika, pendekatan kerja dalam evaluasi menentukan tingkat keterandalan hasil evaluasi keseluruhan. Secara substansial, kegiatan evaluasi merupakan upaya penilaian atas kinerja kegiatan pembangunan (CSR dan CD). Upaya penilaian seperti ini dapat dilakukan baik secara kuantitatif maupun kualitatif. Namun untuk menyajikan hasil pengukuran "tinggi-rendah" atau "baik-buruk" atas suatu keadaan atau capaian, maka akan lebih dapat dipahami, diterima dan dipercaya pengukurannya jika disajikan dalam ukuran kuantitatif. Skala pengukuran ini tidak harus dalam skala rasio melainkan dapat juga dalam skala interval atau bahkan nominal sejauh dapat didefinisikan. Dengan demikian secara substansial kegiatan evaluasi mengisyaratkan preferensi penggunaan pendekatan kuantitatif untuk menunjukan kinerja atau capaian program. Namun hal ini tidak berarti pendekatan kualitatif tidak bermanfaat sama sekali (Patton, 1990). Penjelasan secara kualitatif sangat dibutuhkan guna menerangkan penjelasan lebih mendalam atas sebuah penilaian. Alasan atau sebab lebih jauh tentang sebuah penilaian dapat diperdalam melalui penjelasan secara kualitatif, apalagi jika berkenaan dengan objek yang intangible, misalnya penilaian tentang tingkat "kepuasan", "persetujuan" atau "integrasi sosial". Namun tidak seluruh substansi yang dievaluasi berskala rasio sehingga perlu dikonversi ke dalam penilaian yang dapat dibaca perbedaan antara satu tingkat dengan lainnya. Secara singkat, dapat disebutkan bahwa pendekatan kuantitatif merupakan pendekatan yang kerap digunakan dalam evaluasi program CSR dan CD, namun untuk memperoleh pemahaman lebih dalam diperlukan penilaian dan penjelasan kualitatif untuk melengkapi penilaian kuantitatif tersebut.

3.4 Langkah Kerja Evaluasi. Metode kerja evaluasi program CSR dan CD pada prinsipnya sama dengan metode kerja riset terapan (Wartick, 2002). Ketepatan pilihan jenis metode serta bagaimana memilih prosedur atau langkah kerja yang tepat akan sangat menentukan keseluruhan hasil evaluasi. Artinya, hasil evaluasi hanya dapat dipastikan validitasnya jika dijamin oleh metode riset yang tepat serta dikerjakan dengan proses kerja yang benar secara ilmiah. Penetapan metode yang benar akan memastikan bahwa data yang dikumpulkan, diolah, dianalisis dan disajikan adalah akurat karena dilakukan dengan cara tepat dalam ukuran akademik (CSRM, 2005; CSRM, 2007). Oleh sebab itu, dalam menampilkan laporan evaluasi program sangat penting dijelaskan bagaimana metode kerja yang digunakan.
Pilihan dan ketepatan metode kerja dalam evaluasi program akan memastikan "appropriateness" atau "fit for purpose" atas keseluruhan hasil evaluasi (Denscombe, 2003).

Sejatinya, kerja evaluasi merupakan upaya menilai tinggi-rendahnya kinerja atau capaian suatu kegiatan atau program, serta menetapkan nilai hasil atas apa yang telah dikerjakan. Umumnya penetapan nilai atas suatu keadaan akan lebih bermakna jika disimbolisasikan dalam bentuk angka (numerical) sehingga akan jelas perbedaan "tinggi-rendah", "baik-buruk" atau "berhasilgagal” capaian program. Konsekuensi metodologis dari upaya penilaian seperti ini adalah pendekatan yang relevan untuk digunakan adalah pendekatan deduktif dengan metode riset kuantitatif (King, Lynn, \& Carol, 1987). Dengan pendekatan deduktif, kerangka evaluasi harus diformulasikan terlebih dahulu untuk kemudian dapat digunakan sebagai kerangka menilai kinerja program. Oleh sebab itu, konsep atau variabel yang akan diukur sangat penting untuk didefinisikan batasannya. Konsep sebagai komponen program yang dikerjakan perlu diterjemahkan dan kemudian dielaborasi ke dalam indikator-indikator yang dapat diukur tinggi-rendahnya. Jika indikator sudah dapat ditetapkan maka tugas selanjutnya adalah menetapkan ukuran "tinggi-rendah", atau "baik-buruk" atau "berhasil-gagal.” Walaupun bergantung pada substansi yang hendak diukur, nilai capaian dapat disubstitusi ke dalam angka sehingga akan terlihat perbedaan antara ukuran satu dengan lainnya. Penting dicatat, pengukuran (measuring) tidak harus selalu bersifat kuantitatif melainkan dapat juga bersifat kualitatif (Gauthier, 2005). Namun penilaian kualitatif akan lebih bermakna jika disubstitusi (dikonversikan) ke dalam satuan numerikal agar mudah melihat perbedaan ukuran satu dengan lainnya. Untuk itu perlu dibuat definisi dari masing-masing indikator yang akan digunakan agar kemudian dapat ditentukan ukurannya.

Jika pendekatan dan pengukuran sudah cukup jelas maka penjelasan yang diperlukan selanjutnya adalah memaparkan langkah kerja evaluasi. Langkah kerja evaluasi merupakan prosedur kerja yang turut menentukan tinggi-rendahnya validitas hasil evaluasi. Penjelasan tentang metode evaluasi diperlukan agar dapat dipahami dan dijamin bahwa hasil-hasil evaluasi diperoleh dengan prosedur yang benar secara ilmiah. Secara prinsip, sama dengan riset umumnya, langkah kerja evaluasi dapat dipilah ke dalam empat tahap, yakni pertama, memformulasi disain evaluasi; kedua, mengumpulkan data atau penilaian lapangan; ketiga, merapikan, menyajikan dan menganalisis, dan memberi penilaian data; keempat, membuat laporan dan mengajukan saran dan rekomendasi untuk perbaikan program selanjutnya. Keseluruhan tahap kerja ini merupakan sebuah proses yang berkelanjutan, baiktidaknya pengerjaan satu tahap menentukan tahap 
berikutnya. Dengan pendekatan deduktif, maka tahap formulasi disain evaluasi sangat menentukan tahap berikutnya. Artinya, substansi yang akan dievaluasi serta kualitas data yang akan diperoleh ditentukan oleh bagaimana kesempurnaan disain evaluasi. Dalam tulisan ini akan dibahas khususnya langkah kerja bagaimana membuat formulasi disain.

Formulasi Substansi Evaluasi. Sebagaimana disinggung sebelumnya, substansi evaluasi sangat ditentukan oleh bagaimana perencanaan program pada waktu dibuat, antara lain tujuan dan pendekatan yang digunakan. Oleh karenanya, substansi evaluasi seharusnya merujuk pada tujuan dan capaian yang akan dihasilkan dalam perencanaan program. Untuk memahami lebih jauh tujuan dan capaian, evaluator perlu memahami pendekatan yang digunakan dalam program yang biasanya dijelaskan dalam latar-belakang program, atau secara implisit dan eksplisit tertera dalam tujuan program. Namun pada banyak program CSR dan CD yang dilakukan korporasi tambang dan migas umumnya, tidak tertera secara tegas tujuan dan capaian yang hendak dicapai oleh program. Hal demikian terjadi karena hakekat program CD pada korporasi tambang dan migas umumnya masih bersifat instrumental, yaitu "sekedar" alat untuk membangun komunikasi dan relasi, dan belum menyatu dalam paradigma bisnis mereka.

Selain itu, filosofi bisnis industri ini adalah "eksploitasi” sumber alam, sehingga mungkin sulit bagi industri ini untuk menempatkan CSR dan CD ke dalam proses produksi mereka. Karenanya, program CSR dan CD merupakan "filantropi" saja, sekedar "good will" korporasi terhadap lingkungan sosial sekitar, belum menjadi "social obligation" secara etik (Hennigfeld, Manfred \& Nick, 2006; Griffin, 2000). Pada banyak korporasi tambang dan migas sulit ditemukan sebuah buku program CSR dan CD yang lengkap menyajikan secara tegas dan strategis mengenai tujuan dan capaian yang hendak diwujudkan dalam lima tahun kegiatan program. Keadaan mungkin akan berubah setelah tekanan publik terhadap industri ini semakin kuat, khususnya berkenaan dengan dampak dan manfaat industri terhadap masyarakat lokal di sekitarnya. Berbeda dengan program CSR dan CD pada industri manufaktur dan agribisnis, keberadaan komunitas sekitar merupakan bagian dari proses produksi yang sulit dipisahkan. Bahkan beberapa korporasi perkebunan sudah menyatukan prinsip dan tata-kelola CSR dan CD ke dalam moda produksi mereka, seperti terlihat pada model Perkebunan Inti-Rakyat (PIR), atau seperti model perkebunan teh di Pangalengan, Jawa Barat.

Karena ketiadaan perencanaan program maka jika hendak dievaluasi, substansi CSR dan CD harus diformulasikan terlebih dahulu agar sungguh-sungguh relevan dengan substansi yang hendak dinilai. Pelingkupan substansi ini dapat difokuskan pada kegiatan program yang sudah dilakukan. Namun selain itu, untuk memahami lebih dalam substansi dan pelaksanaan progtam, diperlukan pemahaman tentang tipologi komunitas serta tipologi desa dimana program diimplementasikan. Deskripsi tipologi desa dan komunitas harus secara langsung dikaitkan dengan program CSR dan CD. Selain itu, berkaitan dengan berhasil-tidaknya program CSR dan CD, perlu dipahami bagaimana potensi komunitas dan desa yang bersangkutan, berkenaan dengan ketersediaan sumber daya, organisasi sosial, peluang pasar serta hal terkait lain. Secara garis besar setidaknya dapat dipetakan tiga dimensi substansi penting dalam evaluasi program CSR dan CD, yakni: 1) program CSR dan CD terkait dengan variabel yang hendak dinilai; 2) pemetaan tipologi desa dan komunitas dikaitkan dengan program CSR dan CD; dan 3) pemetaan potensi desa dan komunitas untuk pengembangan program yang relevan (Tabel 2). Selain tiga dimensi ini, substansi evaluasi dapat diperluas dimensi dan variabelnya bergantung kepada cakupan dan kebutuhan penilaian.

Secara substansial dan organisasional, keberhasilan program CSR dan CD ditentukan oleh keadaan pemangku kepentingan penerima. Pada program CSR dan CD yang ditujukan kepada komunitas lokal, tipologi desa/wilayah dan komunitas serta potensi lokal sangat signifikan menetukan berhasil-tidak program (Prayogo dkk., 2007 dan 2008a). Oleh sebab itu, keberhasilan program ditentukan oleh banyak faktor, antara lain perencanaan program, organisasi dan budget. Sejumlah hasil evaluasi yang telah penulis lakukan menunjukkan bahwa sebagian permasalahan dalam program CSR dan CD terletak pada keadaan komunitas itu sendiri, serta bagaimana potensi yang ada pada wilayah (desa) dan komunitas tersebut. Oleh karenanya, dengan melihat dan mempertimbangkan keadaan wilayah dan komunitas serta potensi yang ada pada komunitas, maka sebuah evaluasi program CSR dan CD akan menjadi lebih lengkap, utuh dan obyektif karena dilihat dari cakupan yang lebih komprehensif.

Penetapan Cakupan Wilayah dan Waktu. Selain cakupan subtansi, cakupan wilayah dan waktu sangat penting didefinisikan di muka. Program CSR dan CD industri tambang dan migas biasanya diterapkan pada wilayah yang luas dan tersebar, serta dalam kurun waktu sudah lama atau mungkin baru saja dimulai. Berdasarkan pengalaman penulis hingga sekitar akhir tahun 1990an, jarang sekali dilakukan evaluasi terhadap program CSR dan CD. Hal demikian terjadi karena program CSR dan CD belum banyak dikerjakan, terutama ditujukan lebih karena alasan bisnis dan keamanan, atau sebagai respons atas tekanan dan permintaan masyarakat lokal serta kelompok kepentingan. Program seperti ini lebih sebagai "charity" daripada "responsibility” korporasi terhadap masyarakat di sekelilingnya. Oleh sebab itu evaluasi 
Tabel 2. Substansi Evaluasi

\begin{tabular}{|c|c|c|}
\hline Dimensi & Variabel & Subjek \\
\hline \multicolumn{3}{|c|}{ Tipologi Wilayah dan Komunitas } \\
\hline Tipologi Desa & $\begin{array}{l}\text { Geografi } \\
\text { Demografi } \\
\text { Ekonomi } \\
\text { Infrastruktur publik }\end{array}$ & $\begin{array}{l}\text { Data sekunder/monograf statistik } \\
\text { Data sekunder/monograf statistik } \\
\text { Data sekunder/monograf statistik } \\
\text { Data sekunder/monograf statistik }\end{array}$ \\
\hline Tipologi Komunitas & $\begin{array}{l}\text { Struktur sosial } \\
\text { Kultur sosial } \\
\text { Dinamika hubungan sosial-politik }\end{array}$ & $\begin{array}{l}\text { Masyarakat umum, tokoh informal dan formal } \\
\text { Masyarakat umum, tokoh informal dan formal } \\
\text { Masyarakat umum, tokoh informal dan formal }\end{array}$ \\
\hline \multirow[t]{6}{*}{ Program CSR dan CD } & Manfaat & $\begin{array}{l}\text { Pemanfaat dan non-pemanfaat, tokoh masyarakat, aparat pemda/desa, } \\
\text { staf pelaksana CD, subjek relevan lain }\end{array}$ \\
\hline & Kesesuaian & $\begin{array}{l}\text { Pemanfaat dan non-pemanfaat, tokoh masyarakat, aparat pemda/desa, } \\
\text { staf pelaksana CD, subjek relevan lain }\end{array}$ \\
\hline & Keberlanjutan & $\begin{array}{l}\text { Pemanfaat dan non-pemanfaat, tokoh masyarakat, aparat pemda/desa, } \\
\text { staf pelaksana CD, subjek relevan lain }\end{array}$ \\
\hline & Dampak & $\begin{array}{l}\text { Pemanfaat dan non-pemanfaat, tokoh masyarakat, aparat pemda/desa, } \\
\text { staf pelaksana CD, subjek relevan lain }\end{array}$ \\
\hline & Organisasi & $\begin{array}{l}\text { Pemanfaat dan non-pemanfaat, tokoh masyarakat, aparat pemda/desa, } \\
\text { staf pelaksana CD, subjek relevan lain }\end{array}$ \\
\hline & Dan lain-lain (jika diperlukan) & $\begin{array}{l}\text { Pemanfaat dan non-pemanfaat, tokoh masyarakat, aparat pemda/desa, } \\
\text { staf pelaksana CD, subjek relevan lain }\end{array}$ \\
\hline \multirow[t]{5}{*}{ Potensi } & Sumber alam & Data sekunder, tokoh formal dan informal \\
\hline & Sumber daya manusia & Data sekunder, tokoh formal dan informal \\
\hline & Organisasi & Tokoh formal dan informal \\
\hline & Akses & Data sekunder, tokoh formal dan informal \\
\hline & Dan lain-lain (jika diperlukan) & Data sekunder, tokoh formal dan informal \\
\hline
\end{tabular}

kinerja dan kinerja program tidak penting dilakukan karena manajemen tidak memerlukan hasil apakah progam berjalan baik dan tepat sasaran. Sejauh program dapat menghilangkan atau mengurangi "tekanan sosial”, maka secara umum dinilai berhasil terutama dari sudut kepentingan dan keamanan korporasi.

Dari uraian ini dapat disimpulkan bahwa diperlukan batasan wilayah yang pasti untuk menentukan luasan daerah yang akan dievaluasi, misalnya desa, kecamatan atau kabupaten karena batasan wilayah turut menentukan kinerja program. Jika terlalu luas dan banyak, maka wilayah program perlu dipilah ke dalam beberapa kategori, dan selanjutnya evaluasi dapat dilakukan terhadap sampel wilayah tertentu saja yang mewakili masing-masing kategori. Penetapan batasan wilayah akan memiliki implikasi langsung terhadap lama penelitian, jumlah peneliti yang dibutuhkan serta tentunya biaya penelitian.

Demikian pula dengan batasan waktu. Perlu pembatasan cakupan waktu program yang akan dievaluasi karena hal ini akan menentukan substansi, pola manajemen serta sumber daya yang diinvestasikan. Biasanya cakupan waktu program yang akan dievaluasi pada posisi waktu 2-3 tahun sedang berjalan, atau pada posisi waktu tahun ke-5 di akhir program. Asumsi ini diambil karena program biasanya berdurasi sekitar 5 tahun. Pada posisi 2-3 tahun dapat dilakukan evaluasi pertengahan program dan pada posisi 5 tahun dilakukan evaluasi akhir program. Namun umumnya, evaluasi dilakukan pada akhir program sebagai bentuk evaluasi sumatif untuk dapat diterapkan pada lokasi lain. Jika dilakukan pada posisi 2-3 tahun, evaluasi dapat dikelompokan sebagai evaluasi formatif yang ditujukan untuk penyempurnaan program yang sama pada waktu berikutnya.

Teknik Pengumpulan dan Analisis Data. Jika pengumpulan data telah dilakukan dan data "mentah" (raw data) sudah terkumpul maka pekerjaan berikut adalah merapihkan, menseleksi, mengelompokkan, menyajikan dan menginterpretasi (membaca) data (Cresswell, 1997). Sama seperti pengumpulan data, proses ini dapat diklasifikasi menurut sifat datanya (Tabel 3, Tabel 4). Masing-masing sifat data memiliki kekuatan tersendiri atas informasi yang dikandungnya. Kekuatan data hasil indepth-interview terletak pada peran dan posisi pemberi informasi (informan). Semakin relevan peran dan posisi informan dengan informasi yang dimaksud maka semakin kuat datanya. Kekuatan data hasil observasi terletak pada objekobjektivitas dan ketelitian dari keadaan atau kejadian yang dicatat dan difoto. Terkadang memang 
Tabel 3. Pengumpulan Data

\begin{tabular}{|c|c|c|c|c|}
\hline \multirow{2}{*}{ Tujuan } & \multicolumn{3}{|c|}{ Data Primer } & \multirow{2}{*}{ Data Sekunder } \\
\hline & Indepth & Observasi & Survei & \\
\hline $\begin{array}{l}\text { Mencari data } \\
\text { berkenaan } \\
\text { dengan } \\
\text { tipologi desa } \\
\text { dan komunitas }\end{array}$ & $\begin{array}{l}\text { Alat: pedoman wawancara. } \\
\text { Substansi: seluruh informasi berkaitan } \\
\text { struktur, kultur, dinamika sosial. } \\
\text { Informan: tokoh masyarakat (informal } \\
\text { dan formal): ulama, guru, adat, kades, } \\
\text { karang taruna, asosiasi usaha, polisi, } \\
\text { NGO, pers, korporasi, dan informan } \\
\text { lain yang terkait. } \\
\text { Pemilihan informan: purposif dan } \\
\text { snowball. }\end{array}$ & $\begin{array}{l}\text { Alat: pedoman observasi, dan } \\
\text { foto. } \\
\text { Cara kerja: catat dan foto } \\
\text { kegiatan, kejadian dan bukti } \\
\text { fisik terkait. } \\
\text { Substansi: informasi lain yang } \\
\text { relevan dengan tipologi desa } \\
\text { dan komunitas. }\end{array}$ & $\begin{array}{l}\text { Alat: kuesioner. } \\
\text { Substansi: berkenaan } \\
\text { dengan data demografi } \\
\text { dan ekonomi, } \\
\text { digunakan sebagai data } \\
\text { penunjang. } \\
\text { Sampel: random warga } \\
\text { umum, atau purposif } \\
\text { terhadap warga } \\
\text { kelompok tertentu. }\end{array}$ & $\begin{array}{l}\text { Alat: list kebutuhan data } \\
\text { sekunder. } \\
\text { Substansi: data-data } \\
\text { monograf, baik berkenaan } \\
\text { geografi, demografi, } \\
\text { infrastruktur; maupun } \\
\text { tentang komunitas lokal. } \\
\text { Sumber: pers lokal, dinas } \\
\text { statistik, korporasi, } \\
\text { kecamatan dan kantor desa. }\end{array}$ \\
\hline $\begin{array}{l}\text { Mencari data } \\
\text { berkenaan } \\
\text { dengan } \\
\text { program CSR } \\
\text { dan CD }\end{array}$ & $\begin{array}{l}\text { Alat: pedoman wawancara. } \\
\text { Substansi: seluruh informasi berkaitan } \\
\text { dengan variabel kinerja kegiatan CSR } \\
\text { dan CD. } \\
\text { Informan: pemanfaat, tokoh masyarakat, } \\
\text { institusi relevan, staf CD, NGO. } \\
\text { Pemilihan informan: purposif dan } \\
\text { snowball. }\end{array}$ & $\begin{array}{l}\text { Alat: pedoman observasi, dan } \\
\text { foto. } \\
\text { Cara kerja: catat dan foto } \\
\text { kegiatan, kejadian dan bukti } \\
\text { fisik terkait. } \\
\text { Substansi: informasi lain yang } \\
\text { relevan dengan program CSR } \\
\text { dan CD. }\end{array}$ & $\begin{array}{l}\text { Alat: kuesioner. } \\
\text { Substansi: berkenaan } \\
\text { dengan variabel } \\
\text { program CSR dan CD } \\
\text { yang dievaluasi. } \\
\text { Sampel: random } \\
\text { pemanfaat dan non- } \\
\text { pemanfaat. }\end{array}$ & $\begin{array}{l}\text { Alat: list kebutuhan data } \\
\text { sekunder. } \\
\text { Substansi: data-data } \\
\text { penunjang berkenaan } \\
\text { kegiatan CSR dan CD. } \\
\text { Sumber: kantor CD } \\
\text { korporasi, kantor desa dan } \\
\text { kecamatan. }\end{array}$ \\
\hline $\begin{array}{l}\text { Mencari data } \\
\text { berkenaan } \\
\text { dengan } \\
\text { potensi CSR } \\
\text { dan CD }\end{array}$ & $\begin{array}{l}\text { Alat: pedoman wawancara. } \\
\text { Substansi: seluruh informasi terkait } \\
\text { dengan potensi lokal untuk CSR dan } \\
\text { CD. } \\
\text { Informan: tokoh masyarakat formal } \\
\text { dan informal, staf CD, pers dan NGO. } \\
\text { Pemilihan informan: purposif dan } \\
\text { snowball. }\end{array}$ & $\begin{array}{l}\text { Alat: pedoman observasi, dan } \\
\text { foto. } \\
\text { Cara kerja: catat dan foto } \\
\text { kegiatan dan bukti fisik } \\
\text { terkait dengan potensi lokal } \\
\text { untuk CSR dan CD. } \\
\text { Substansi: informasi lain yang } \\
\text { relevan dengan program CSR } \\
\text { dan CD. }\end{array}$ & $\begin{array}{l}\text { Alat: kuesioner } \\
\text { Substansi: berkenaan } \\
\text { dengan potensi yang } \\
\text { dipikirkan responden. } \\
\text { Sampel: random warga } \\
\text { pemanfaat dan non- } \\
\text { pemanfaat. }\end{array}$ & $\begin{array}{l}\text { Alat: list kebutuhan data } \\
\text { sekunder. } \\
\text { Substansi: data-data } \\
\text { penunjang berkenaan } \\
\text { potensi CSR dan CD. } \\
\text { Sumber: kantor CD } \\
\text { korporasi, kantor desa dan } \\
\text { kecamatan. }\end{array}$ \\
\hline
\end{tabular}

Sumber: Adaptasi dari Prayogo, 2008b.

Tabel 4. Analisis Data Hasil

\begin{tabular}{|c|c|c|c|c|}
\hline \multirow{2}{*}{ Teknik } & \multicolumn{3}{|c|}{ Data Primer } & \multirow{2}{*}{ Data Dekunder } \\
\hline & Hasil Indepth & Hasil Observasi & Hasil Survei & \\
\hline Alat Kerja & $\begin{array}{l}\text { Matrik dengan } \\
\text { meringkas substansi } \\
\text { pokok hasil } \\
\text { wawancara dan } \\
\text { memasukanya ke } \\
\text { dalam sel matriks. }\end{array}$ & $\begin{array}{l}\text { Matriks dan tabulasi hasil } \\
\text { catatan observasi serta } \\
\text { pengelompokan foto } \\
\text { terkait dengan masing- } \\
\text { masing variabel evaluasi. }\end{array}$ & $\begin{array}{l}\text { Program SPSS, Excel serta } \\
\text { program terkait yang diperlukan. }\end{array}$ & $\begin{array}{l}\text { Matriks dan tabel hasil } \\
\text { tabulasi angka, serta untuk } \\
\text { kesimpulan penting data } \\
\text { sekunder kualitatif. }\end{array}$ \\
\hline Cara Kerja & $\begin{array}{l}\text { Formulasi matrik hasil } \\
\text { wawancara dengan } \\
\text { melakukan silang } \\
\text { secara ringkas antara } \\
\text { informan dengan } \\
\text { variabel atau substansi } \\
\text { hasil wawancara. }\end{array}$ & $\begin{array}{l}\text { Meringkas dan memilah } \\
\text { berdasarkan substansi } \\
\text { hasil catatan observasi } \\
\text { dan foto. }\end{array}$ & $\begin{array}{l}\text { Proses statistik dengan SPSS, } \\
\text { tabulasi dan presentasi data. }\end{array}$ & $\begin{array}{l}\text { Memilah, seleksi, } \\
\text { kategorisasi, klasifikasi } \\
\text { dan tabulasi data } \\
\text { terkumpul. }\end{array}$ \\
\hline Cara memahami data & $\begin{array}{l}\text { Melihat penonjolan } \\
\text { informasi jawaban } \\
\text { informan. Kekuatan } \\
\text { dan kualitas data } \\
\text { informasi ditentukan } \\
\text { oleh posisi dan peran } \\
\text { informan. }\end{array}$ & $\begin{array}{l}\text { Melihat catatan dan hasil } \\
\text { foto dengan mengkaitkan } \\
\text { dengan variabel yang } \\
\text { dimaksud. Data hasil } \\
\text { observasi dapat } \\
\text { diperlakukan sebagai hard } \\
\text { evidence. }\end{array}$ & $\begin{array}{l}\text { Menilai kecenderungan numerikal } \\
\text { dari penonjolan median, modus } \\
\text { serta kakuatan hubungan antar } \\
\text { variabel (jika dilakukan silang } \\
\text { data). Secara kuantitatif hasil SPSS } \\
\text { sudah menuntun penonjolan data } \\
\text { untuk kesimpulan penilaian. }\end{array}$ & $\begin{array}{l}\text { Interpretasi penonjolan } \\
\text { informasi dan } \\
\text { mengkaitkan dengan data } \\
\text { lain (primer dan } \\
\text { sekunder). }\end{array}$ \\
\hline
\end{tabular}

diperlukan interpretasi hasil catatan observasi karena data tidak bersifat fisik melainkan perilaku. Data hasil survei sangat kuat pada penonjolan angka (persentase jika deskriptif) dan penonjolan numerikal secara statistik, misalnya persentase, modus, mean dan kekuatan hubungan (Neuman, 1994). Data hasil survei pada dasarnya sudah menuntun kepada kesimpulan hasil penelitian karena penonjolan angka pada sampel menunjukan keadaan pada populasi yang diteliti (inferensi). Sementara pada data sekunder, khususnya data kuantitatif, kekuatannya terletak pada agregasi dan penonjolan angka setelah dilakukan seleksi, klasifikasi dan tabulasi data. Penonjolan persentase atau angka absolut menunjukan keadaan pada wilayah atau populasi 
dimaksud. Untuk data sekunder kualitatif, kekuatannya terletak pada informasi berita dan opini dari informan yang peran dan statusnya paling tepat untuk informasi dimaksud (Patton, 1990). Dengan cara analisis dan interpretasi data seperti ini maka objektivitas hasil evaluasi dapat dipertahankan, tentunya netralitas dalam pemahaman data diperlukan dari evaluator.

Dengan cara dan prosedur pengumpulan dan analisis data seperti di atas maka dapat dipastikan bahwa metode dan prosedur pengumpulan dan analisis data adalah benar secara ilmiah. Pada pengumpulan dan analisis data kuantitatif, peran peneliti (evaluator) lebih sebagai "operator" karena instrumen penelitian sudah didisain secara terstruktur dan detil. Kesalahan dan kelemahan pada kualitas dan validitas terletak lebih pada instrumennya bukan peneliti. Sementara pada pengumpulan data kualitatif, walaupun dibuat instrumen, peran peneliti sangat besar, baik terhadap sumber, substansi maupun interpretasi data. Peran peneliti lebih sebagai instrumen sekaligus analisator terhadap data. Oleh sebab itu untuk melakukan pengumpulan data kualitatif diperlukan peneliti cukup senior untuk melakukanya. Secara keseluruhan, jika metode dan prosedur di atas sudah dapat dilaksanakan sebagaimana mestinya maka data untuk penilaian dalam evaluasi sudah memenuhi kualitas dan validitas sebagai dasar penetapan penilaian berikutnya.

Penetapan Sampel, Informan, Objek Observasi dan Data Sekunder. Salah satu hal yang cukup penting dirumuskan dalam disain evaluasi adalah menetapkan subjeksubjek dan objekobjek evaluasi. Untuk memenuhi keharusan ilmiah dan menjamin validitas hasil evaluasi maka perlu dilakukan: 1) perumusan sampel untuk survei, 2) penetapan informan untuk depth interview, 3) penetapan objekobjek untuk observasi, 4) penetapan data sekunder yang dibutuhkan. Pertama, khususnya untuk penarikan sampel responden dalam survei, penetapan sampling sangat menentukan validitas dan kualitas data. Penetapan jumlah sampel biasa menggunakan rumus statistik yang ditarik dari jumlah populasi. Namun dari pengalaman lapangan penulis perumusan jumlah sampel secara statistik seperti ini sulit dilakukan karena jumlah sampel harus disesuaikan dengan komposisi jenis dan jumlah program, serta disesuaikan dengan lokasi populasi yang tersebar pada sejumlah desa, kecamatan, kabupaten bahkan propinsi. Pertimbangan lain yang perlu dimasukan adalah waktu dan dana untuk studi lapangan yang tentunya ada batasnya. Menimbang tentangan seperti ini maka jumlah sampel diupayakan tidak terlalu besar namun masih cukup proporsional dengan jumlah populasi pemanfaat program, serta memadai untuk dilakukan analisis statistik. Untuk itu jumlah sampel pemanfaat dapat ditetapkan minimum 75 responden dan maksimum 300 responden, disesuaikan dengan besar-kecilnya cakupan program dan jumlah populasi.

Selanjutnya, hal paling penting dalam penarikan sampel adalah menentukan bagaimana teknik sampling. Secara statistik teknik random (acak) adalah cara yang mutlak dilakukan guna menjamin bahwa setiap anggota populasi memiliki probabilita yang sama untuk dijadikan sampel (memberikan penilaian) (Neuman, 1994). Artinya, teknik sampling dengan random ditujukan untuk menghasilkan inferensi sampel terhadap populasi secara optimum. Sampel adalah miniatur dari populasi, dan jika dilakukan survei penilaian program maka penilaian sampel secara statistik persis sama dengan penilaian populasi. Namun kendala di lapangan kerap memaksa peneliti menggunakan teknik lain, karena memang tidak tersedia data populasi pemanfaat program, sehingga teknik random tidak dapat dilakukan. Cara lain yang dapat digunakan adalah dengan menggunakan teknik purposive dan snowball. Secara statistik cara ini kurang disarankan untuk menjamin prinsip inferensi, namun karena keadaan lapangan kadang terpaksa dilakukan. Dengan cara ini prinsip probabilita berkurang namun survei untuk penilaian masih tetap dapat dilakukan. Jika cara kedua ini yang dilakukan maka harus djelaskan dalam metodologi sebagai kelemahan metodologi sehingga tidak menimbulkan perdebatan dan keraguan atas hasil evaluasi lebih lanjut.

Kedua, penetapan informan untuk wawancara mendalam lebih mudah daripada melakukan penetapan sampel. Hal pokok yang perlu ditegaskan dalam penetapan informan adalah kriteria informan kunci sebagaimana yang dibutuhkan agar peneliti memperoleh informasi yang dimaksud. Penetapan kriteria ini akan merujuk pada peran dan posisi informan yang dibutuhkan untuk wawancara mendalam. Misalnya untuk mengetahui pemanfaatan program dapat diwawancarai pemanfaat yang paling aktif dalam program, ketua kelompok, kepala desa serta staf pelaksana program di lapangan. Selanjutnya, setelah kriteria informan ditetapkan maka dapat dibuat daftar informan yang akan diwawancarai. Pada prinsipnya peran dan posisi informan tidak dapat diwakili, sehingga jika informan yang dimaksud sulit ditemui maka harus diupayakan untuk dapat ditemui dan diwawancara, misalnya melalui telepon atau media lain. Kekuatan informasi dari wawancara mendalam adalah pada kompetensi informanya, yakni semakin absah dan dekat posisi subjek dengan informasi yang dibutuhkan maka semakin valid dan kuat data yang terkumpul (Patton, 1990).

Ketiga, observasi perlu dilakukan baik terhadap kegiatan, objek fisik atau momen peristiwa yang berkaitan dengan fokus evaluasi. Untuk mengumpulkan data ini dapat dilakukan perencanaan sebelumnya dengan menetapkan keadaan, kegiatan dan peristiwa apa yang perlu direkam dan ditatat, serta bagaimana teknik observasi dilakukan. Misalnya, untuk membuktikan bahwa program air bersih berjalan baik maka dapat diobservasi kegiatan masyarakat yang terkait dengan program ini, merekamnya dalam video atau foto serta mencatat hal-hal penting, yang kemudian dapat menjadi data evaluasi program dimaksud. Hasil observasi 
merupakan hard evidence, bukti nyata yang mendukung hasil-hasil evaluasi. Pernyataan tentang ada-tidak, baikburuk, dan berhasil-gagal salah satunya dapat ditunjukan oleh data-data hasil obervasi. Data hasil survei dan wawancara mendalam memang memiliki "makna” penting namun masih merupakan ungkapan subjek, dan akan lebih kuat jika pernyataan atau pendapat tersebut didukung oleh hard evidence hasil observasi (Cresswell, 1997). Untuk itu yang perlu dipersiapkan untuk melakukan observasi dengan membuat kerangka observasi, berisi daftar objek, kegiatan atau peristiwa yang penting diamati, kapan waktunya serta bagaimana melakukannya.

Keempat, data sekunder dapat diperlakukan sebagai data awal dan data pendukung yang sangat penting. Sebelum evaluasi lapangan dilakukan, evaluator harus mengumukan data sekunder sebagai data yang dapat menuntunnya dalam membuat disain evaluasi. Selanjutnya, data sekunder dapat dikumpulkan saat penelitian lapangan untuk digunakan sebagai data pembuktian dan memperkuat penilaian peneliti. Data sekunder yang diperlukan, selain tentunya berkenaan dengan program yang akan dievaluasi, juga berkenaan dengan keadaan masyarakat lokasi program. Khusus data sekunder program, penting dikumpulkan data tentang perencanaan atau disain program, laporan tahunan, realisasi dan hasil monitoring, organisasi, budget, staf yang terlibat. Data ini secara keseluruhan turut memberi informasi tentang visi dan misi, tujuan, capaian, dampak diharapkan, hasil pelaksanaan, hasil capaian, manajemen, serta capaian-capaian program yang berhasil dicatat. Data sekunder tentang desa dan masyarakat setempat yang perlu dikumpulkan berkenaan dengan data demografi, ekonomi, infrastruktur, serta geografi secara terbatas. Untuk melengkapi data ini jika dimungkinkan penting pula dikumpulkan artikel kajian atau ulasan yang mungkin pernah diterbitkan dalam jurnal atau media adalah data yang berkaitan dengan program yang dievaluasi.

Penetapan Subjek Penilai. Masalah penting lain perlu dibahas adalah siapa atau pihak mana yang memiliki kompetensi pemberi penilaian dalam evaluasi. Telah disinggung bahwa bias bisa terjadi pada semua pihak yang terlibat dalam program dan penelitian evaluasi, bisa terjadi pada evaluator, pelaksana program, pemanfaat (beneficiaries), perancang serta penyedia dana. Khususnya pada substansi penilaian program CSR dan CD, tentu akan ada banyak pertimbangan yang patut diperhitungkan karena masing-masing pemberi nilai memiliki kepentingan dan persepsi secara subjektif terhadap objek yang dinilainya (Mahon, 2002; Wartick, 2002). Oleh karenanya prinsip triangulasi perlu diaplikasikan dalam evaluasi program. Tetapi karena tidak seluruh subjek memiliki pengetahuan mendalam tentang program yang akan dievaluasi, maka pemilihan subjek penilai harus dilakukan secara seksama. Untuk mencapai objektivitas penilaian yang optimum, maka penilaian multipemangku kepentingan perlu dilakukan.
Setidaknya terdapat tiga pemangku kepentingan penting yang penilaiannya dalam survei kuantitaif, yakni 1) pemanfaat, 2) pelaksana program dan 3) peneliti atau evaluator. Selebihnya, pemangku kepentingan lain seperti non-pemanfaat, pemerintah daerah, pers, NGO, atau pemangku kepentingan lain dapat diakomodasi opininya melalui wawancara mendalam.

Pemanfaat program merupakan penilai keberhasilan program yang mutlak harus dimasukan dalam kelompok penilai khususnya dalam survei. Dapat dikatakan pemanfaat program merupakan pemangku kepentingan utama yang memiliki keabsahan paling tinggi untuk memberi nilai program yang diterimanya. Penilaian pemanfaat dalam survei dapat digunakan sebagai ukuran utama tentang berhasil-tidaknya atau baik-buruknya program. Namun demikian tetap saja kerap muncul subjektivitas pemanfaat karena perbedaan kepentingan, harapan serta ukuran subjektif tentang nilai program. Misalnya tentang "dampak“ program, kerap pemanfaat tidak memiliki pemahaman memadai tentang variabel ini sehingga apa arti dampak dan bagaimana ia dapat memberi nilai atas variabel ini tidak memadai dan obyektif. Bias, baik karena ketidaktahuan maupun sarat akan kepentingan subjek, dapat terjadi pada para pemanfaat. Bahkan kerap pemanfaat memiliki harapan dan ekspektasi terlalu besar terhadap program sehingga nilai yang diberikan terhadap kinerja program menjadi rendah walaupun secara obyektif program sudah dijalankan secara baik.

Sebaliknya pada subjek perencana dan pelaksana program, karena berkepentingan terhadap kinerja dan prestasi kerja mereka, bias penilaian dapat terjadi dengan memberi nilai terlalu tinggi terhadap apa yan telah mereka lakukan. Jika ada kelemahan maka cederung ditempatkan kepada kelompok penerima atau institusi lain. Memang ada sebagian kasus perencana dan pelaksana program berupaya untuk bersikap netral dan obyektif terhadap program karena mereka berkepentingan untuk memperbaiki program untuk siklus kegiatan berikutnya. Pada satu sisi, perencana dan pelaksana program merupakan pihak yang paling memahami visi, misi, tujuan dan bahkan "hidden agenda" di balik program (jika ada). Oleh sebab itu, kepentingan mereka dapat muncul dalam pelaksanaan program sehingga dapat terjadi bias dalam evaluasi. Untuk mengimbangi bias dari dua institusi yang dapat "berseberangan" penilaiannya_-perencana dan pelaksana program versus pemanfaat program-diperlukan penilai ketiga yakni evaluator itu sendiri.

Evaluator, dengan integritas moral dan pengetahuannya, akan berupaya memberi penilaian seobyektif mungkin terhadap program sebagai objek evaluasi. Jika terjadi perbedaan tajam dalam penilaian antara pemanfaat dan pelaksana program, maka posisi evaluator lebih dapat diterima sebagai pihak netral. Namun kelemahan 
evaluator adalah, pegalaman emosional dan pemahaman mendalam mereka tentang latar-belakang disain program serta proses pelaksanaan program tidaklah sama dengan perencana dan pelaksana program serta pemanfaat program. Emotional involvement evaluator lebih dangkal dibanding keduanya sehingga kerap dipandang kurang memahami makna program. Evaluator mungkin tidak mengetahui "hidden agenda" dibanding perencana program. Selanjutnya evaluator tidak memiliki harapan dan keinginan sebagaimana pemanfaat program. Lebih dari itu, posisi evaluator memang harus "mengambil jarak" dengan objek dan subjek yang dievaluasi sehingga dalam kapasitas ini penilaian evaluator lebih "bebas nilai" dan "bebas emosional“. Untuk itu guna mencapai titik objektivitas penilaian optimum ketiga pihak ini perlu dilibatkan sebagai pemberi nilai dalam evaluasi program.

Hal lain yang perlu dipertimbangkan adalah pemangku kepentingan lain yang terkait dengan program. Pendapat dan aspirasi komunitas, seperti tokoh masyarakat, staf pemerintah, NGO, pers dan masyarakat umum penting pula diliput guna memperkaya pemahaman tentang komunitas dan saran bagi perbaikan program selanjutnya. Pendapat mereka memang hanya dapat diakomodasi berkenaan dengan aspek secara umum saja dari program, seperti bagaimana keinginan dan kemampuan warga, saran dan pemecahan masalah dari sisi komunitas, potensi dan kelemahan komunitas, atau hal lain yang dapat memperkaya pemahaman peneliti tentang komunitas dan program yang dievaluasi. Oleh karenanya, pendapat komunitas lain perlu diliput secara selektif dan melalui wawancara kualitatif. Penilaian komunitas secara kuantitatif terhadap program sulit dilakukan karena umumnya mereka tidak mengetahui detil dari program sehingga beresiko untuk terjadi bias dalam penilaian.

Cara Pengukuran dalam Evaluasi. Pengukuran (measurement) merupakan bagian sangat penting dalam kegiatan evaluasi. Perbedaan dalam ukuran yang digunakan oleh masing-masing evaluator akan memunculkan hasil penilaian tingkat keberhasilan yang berbeda. Demikian pula bagi pembaca atau pengguna hasil evaluasi, sanggahan dapat muncul terhadap hasil evaluasi karena terdapat perbedaan dalam pengukuran kinerja program. Selain itu masing-masing pihak memiliki metode berbeda tentang bagaimana mengukur suatu keadaan atau capaian kerja. Oleh sebab itu, sebelum hasil penilaian disajikan, perlu dijelaskan terlebih dahulu bagaimana cara pengukuran yang digunakan oleh evaluator. Hal ini penting untuk membangun persepsi yang sama antara evaluator (penulis) dan pengguna (pembaca) terhadap hasil evaluasi. Perdebatan biasanya muncul bukan pada nilai hasil evaluasi, melainkan tentang metode dan pengukuran yang digunakan oleh evaluator. Nilai program merupakan hasil akhir dari bagaimana metode dan ukuran yang digunakan, merupakan hasil dari sebuah proses. Oleh karenanya, perlu dijelaskan proses, khususnya tentang ukuran yang digunakan untuk menjamin validitas dan objektivitas guna menghasilkan legitimasi maksimum dari kalangan luas.

Khusus untuk pemanfaat sebagai penilai dalam survei, penilaian mereka, misalnya tentang “manfaat” program, harus disesuaikan dengan pengalaman mereka sejalan dengan apa yang mereka rasakan dan pikirkan tentang konsep "manfaat" dalam pemahaman keseharian mereka. Akan sulit untuk memaksa ukuran konsep "manfaat" dari pemanfaat ke dalam ukuran peneliti. Ukuran tinggi-rendah tingkat "manfaat” program dalam perpektif pemanfaat harus disederhanakan dengan kembali merujuk kepada pengalaman mereka seharihari. Cara yang paling mudah memperoleh nilai dari pemanfaat adalah menanyakan kepada mereka dengan cara meminta mereka memberi nilai dalam angka, misalnya angka 1-10. Cara ini jauh lebih mudah digunakan daripada "memaksakan" pemanfaat mengatakan "sangat buruk" atau "sangat baik". Kemudian angka yang disebutkan, misalnya 8 dari rentang 1-10, kemudian dapat dikonversikan ke dalam rentang nilai 1 hingga 5, sehingga masuk ke dalam kategori angka 4. Dalam rentang penilaian ini, nilai 1 dapat digunakan sebagai substitusi dari kondisi "sangat buruk”, nilai 2 sebagai "buruk”, nilai 3 sebagai "cukup”, nilai 4 sebagai "baik” dan nilai 5 sebagai "sangat baik". Dengan demikian, maka nilai 8 dari "manfaat” program menurut seorang responden adalah sama dengan kategori "baik". Substitisi nilai dalam skala nominal seperti ini, dari angka menjadi kategori kualitatif atau sebaliknya, dapat digunakan untuk menjelaskan "keadaan" dari objek yang dinilai sejalan dengan stock of knowledge yang dimiliki pemanfaat sebagai reaponden survei. Selanjutnya, ukuran 1-5 sebagai substitusi dari nilai "sangat buruk" hingga "sangat baik" dapat digunakan untuk penilaian oleh subjek yang lain seperti peneliti dan staf CD (perencana dan pelaksana).

Jika pemanfaat memberi nilai dengan merujuk kepada pengalaman mereka, maka evaluator menilai keberhasilan melalui kategori yang dibangun sebelumnya dan membandingkannya dengan data yang diperoleh. Data diperoleh sebagai dasar penilaian adalah data hasil wawancara mendalam, observasi dan data sekunder yang mungkin turut menunjang. Data hasil survei sepenuhnya digunakan sebagai hasil penilaian pemanfaat, sehingga tidak perlu lagi digunakan oleh peneliti untuk memberi penilaian lebih lanjut. Kategori ini dapat berbentuk ukuran lebih numerikal dengan memperkirakan prosentase kelompok yang menikmati program. Contoh kategori penilaian peneliti tertera pada Tabel 5.

Pengukuran peneliti (evaluator) mendasarkan penilaiannya pada data hasil wawancara dan observasi (utamanya) melalui upaya kuantifikasi tingkat “manfaat” program. Cara ini tentunya berbeda dari cara pengkuran yang digunakan pemanfaat. Walaupun hanya sebuah contoh, logika pengukuran ini sangat disarankan digunakan dalam melakukan penilaian evaluasi, yakni melakukan substitusi sehingga kinerja tingkat 


\section{Tabel 5. Contoh Kriteria Penilaian Peneliti}

Dapat didefinisikan bahwa, tingkat manfaat program adalah seberapa jauh program yang dilaksanakan dapat meringankan beban masyarakat atau seberapa jauh program tersebut dapat dipergunakan oleh masyarakat dalam berbagai aktivitas mereka sehari-hari. Kriteria penilaian tingkat manfaat dilihat dari beberapa hal, yaitu:

1) Lebih dari $50 \%$ program/bantuan dapat digunakan pada aktivitas masyarakat atau dapat meringankan beban pemanfaat sehari-hari. Adapun untuk program pemberdayaan ekonomi dapat menjadi sumber pendapatan alternatif keluarga.

2) Lebih dari 50\% program/bantuan dapat dirasakan langsung manfaatnya oleh penerima.

3) Jumlah pemanfaat langsung lebih dari 50\% penerima program/bantuan.

4) Lebih dari $50 \%$ program/bantuan dimanfaatkan oleh komunitas yang heterogen (tidak hanya dinikmati oleh golongan/kelompok masyarakat tertentu.

5) Jumlah program yang diakui adanya manfaat oleh kelompok masyarakat non-pemanfaat berjumlah lebih dari 50\% dari jumlah program/bantuan.

Sumber: Irvan dalam Prayogo dkk. (2008)

\section{Tabel 6. Indeks Nilai Capaian}

CD Index merupakan penjumlahan nilai dari empat indikator (variabel manfaat, kesesuaian, keberlanjutan dan dampak) dan dibagi 4. Skor maksimal adalah 5 x 4 (20), dan skor minimal adalah 1 x 4 (4), dengan kategori nilai "sangat baik", "baik", "cukup", "kurang", dan "sangat kurang"; maka intervalnya adalah $(20-4): 5=3,19$. CD Index ini menggunakan asumsi seluruh peneliti telah menggabungkan penilaian menjadi satu nilai yang disepakati. Skor total, interval, dan rentang penilaian akan berbeda bila masing-masing peneliti belum menggabungkan nilai yang diberikan kepada tiap-tiap indikator.

Sumber: Irvan dalam Prayogo dkk. (2008ª)

Tabel 7. Contoh Penetapan Indeks Kinerja Program

\begin{tabular}{|c|c|c|c|c|c|c|c|c|c|c|}
\hline \multirow{2}{*}{ Program } & \multicolumn{2}{|c|}{ Manfaat } & \multicolumn{2}{|c|}{ Kesesuaian } & \multicolumn{2}{|c|}{ Keberlanjutan } & \multicolumn{2}{|c|}{ Dampak } & \multicolumn{2}{|c|}{ Rata-rata } \\
\hline & $\mathrm{B}$ & $\mathrm{R}$ & $\mathrm{B}$ & $\mathrm{R}$ & $\mathrm{B}$ & $\mathrm{R}$ & $\mathrm{B}$ & $\mathrm{R}$ & $\mathrm{B}$ & $\mathrm{R}$ \\
\hline Pendidikan & 4 & 4 & 4 & 4 & 3 & 5 & 4 & 5 & 3.75 & 4.50 \\
\hline Kesehatan & 3 & 3 & 5 & 4 & 4 & 5 & 4 & 4 & 4.00 & 4.00 \\
\hline Ekonomi & 4 & 4 & 3 & 3 & 3 & 4 & 3 & 3 & 3.25 & 3.50 \\
\hline Infrastruktur & 3 & 4 & 4 & 5 & 4 & 3 & 4 & 4 & 3.75 & 4.00 \\
\hline Lingkungan & 2 & 4 & 3 & 4 & 3 & 4 & 3 & 3 & 2.75 & 3.75 \\
\hline Donasi & 5 & 3 & 4 & 3 & 2 & 3 & 2 & 2 & 3.25 & 2.75 \\
\hline Total Mean & 3.5 & 3.6 & 3.8 & 3.8 & 3.2 & 4 & 3.3 & 3.5 & 3.45 & 3.75 \\
\hline
\end{tabular}

= nilai rata-rata yang diberikan pemanfaat; $\mathrm{R}$ = nilai rata-rata yang diberikan peneliti; nilai hanya bersifat contoh saja.

keberhasilan program dapat ditunjukan secara lebih tegas perbedaan antara kategori satu dengan lainya. Dengan penyajian seperti ini maka pengguna atau pembaca evaluasi akan lebih mudah memahami nilai dan derajat tinggi-rendah kinerja program jika terhadapnya diberikan penilaian numerikal.

Untuk lebih memperkuat penilaian peneliti dapat dibuat indeks penilaian dengan menggabungkan dan mengeluarkan nilai rata-rata dari keseluruhan indikator atau variabel yang digunakan (lihat Tabel 6). Misalnya dengan menggunakan empat indikator-yakni manfaat, kesesuaian, keberlanjutan dan dampak-dari hasil penialan peneliti dapat dihasilkan indeks kinerja program secara keseluruhan. Nilai indeks merupakan nilai gabungan dari empat indikator hasil penilaian keseluruhan evaluator. Nilai evaluator merupakan nilai rata-rata keseluruhan yang diberikan masing-masing peneliti yang turut dalam penelitian lapangan sehingga memahami fakta obyektif di lapangan. Cara yang sama dapat dilakukan terhadap hasil survei pemanfaat. Nilai indeks penilaian pemanfaat merupakan nilai total gabungan dari empat indikator yang disurvei. Nilai indeks pemanfaat dapat diperbandingkan dengan nilai peneliti, sehingga akan terlihat bagaimana perbedaan penilaian. Untuk mencari nilai secara umum dapat dihitung berapa nilai gabungan rata-rata antara nilai yang diberikan responden dan peneliti (lihat contoh Tabel 7).

Pada contoh Tabel 7 terlihat perbedaan penilaian antara pemanfaat dengan peneliti. Secara keseluruhan nilai rata-rata yang diberikan peneliti lebih tinggi daripada nilai rata-rata yan diberikan pemanfaat. Berbagai alasan dapat mendasari perbedaan ini baik karena perbedaan stock of knowledge maupun perbedaan kepentingan atau harapan. Dengan perbedaan angka ini pengguna (pembaca) dapat melihat variasi tersebut sehingga dapat 
memahami secara lebih obyektif. Namun dengan adanya dua penilaian ini maka objektivitas penilaian lebih tinggi daripada jika hanya digunakan satu penilaian saja. Bias masing-masing penilai dapat dikurangi dengan menyajikan perbandingan dengan indeks nilai yang berbeda. Kemudian, mengenai penilaian staf perencana dan pelaksana program, penilaian mereka dapat ditambahkan secara khusus menjadi penilaian ketiga. Jika penilaian pelaksana dan perencana dapat dimunculkan maka akan memperkaya sekaligus mengurangi kemungkinan bias masing-masing pihak. Namun karena umumnya jumlah staf program tidak banyak, maka penilaian merfeka hanya dapat ditanyakan secara kualitatif saja, dan hasil penilaian ini dapat dirata-ratakan dan dimasukan ke dalam kolom ketiga. Jika nilai staf dapat dimasukan maka penilaian akan lebih obyektif dan prinsip triangulasi untuk netralitas dapat diwujudkan.

3.5 Penyimpulan Hasil Evaluasi. Jika pengumpulan dan analisis data sudah dilakukan dan hasil penilaian telah diformulasikan maka tugas penting berikutnya adalah merumuskan kesimpulan evaluasi serta memberikan rekomendasi bagi perbaikan program selanjutnya. Penarikan kesimpulan harus dilakukan secara hati-hati dan rasional. Terdapat tiga hal penting yang perlu diperhatikan dalam melakukan penyimpulan: pertama, kesimpulan merupakan pernyataan hasil umum dan pokok; kedua, penjelasan tentang kesimpulan harus logis; dan paling penting, ketiga, penjelasan didukung oleh data yang kuat. Dengan demikian, kesimpulan hasil evaluasi merupakan intisari dari temuan hasil penelitian. Secara kuantitatif kesimpulan penilaian dapat dilihat dari tabel indeks kinerja program (Tabel 7). Dari tabel ini dapat ditarik kesimpulan pokok, seperti (hanya sekedar contoh) "dari keenam bidang program, menurut pemanfaat, program kesehatan adalah bidang yang paling baik kinerjanya; sementara menurut evaluator, yang terbaik adalah program pendidikan”. Selain itu, jika diperhatikan tabel yang sama, "program lingkungan adalah yang terburuk kinerjanya menurut pemanfaat; sementara menurut evaluator adalah program donasi”. Kesimpulan ini ditetapkan berdasarkan data yang tertera dalam indeks nilai. Selanjutnya, untuk memastikan bahwa kesimpulan tersebut benar dan kuat, penjelasan logis diperlukan untuk menjelaskan mengapa ada program dengan dinilai terbaik dan mengapa terjadi perbedaan penilaian. Penjelasan logis harus didukung oleh data, merujuk kepada hasil wawancara mendalam, observasi dan data sekunder, apakah keseluruhannya mendukung atau tidak kesimpulan tersebut. Dengan cara ini maka terdapat kaitan erat antara kesimpulan penilaian, penjelasan logis dan data sebagai dasar penarikan kesimpulan.

Selanjutnya rekomendasi dapat dibangun dari hasil kesimpulan tersebut. Hasil data yang lain (wawancara, observasi dan data sekunder) menjelaskan mengapa terjadi penilaian demikian, sekaligus data-data ini juga menjelaskan berhasil-tidaknya program tersebut. Penjelasan baik-buruk dan berhasil-tidak dengan sendirinya sudah mengungkapkan kekuatan dan kelemahan program. Berdasarkan identifikasi penilaian program maka rekomendasi perbaikan dapat dikembangkan dengan merujuk kembali kepada tujuan dan model ideal bagaimana CSR dan CD direncanakan. Rekomendasi merupakan saran perbaikan yang perlu dilakukan, bisa sangat detil jika penting sekali, atau cukup secara umum saja, guna perbaikan program selanjutnya. Pada tahapan ini, evaluasi telah berhasil menunjukan bagamana kinerja capaian program, membandingkan kembali dengan tujuan dan target program, serta memperlihatkan kekuatan dan kelemahan program. Dari paparan ini dapat dibuat identifikasi permasalahan tentang kelemahan (dan kekuatan agar seimbang) program yang ada, misalnya bagaimana permasalahan penting yang terdapat pada program tersebut. Contoh dalam Tabel 8 hanya contoh sederhana saja. Dari gambaran tersebut, untuk menghasilkan rekomendasi yang baik dan bermanfaat penting diperhatikan bagaimana evaluator merumuskan permasalahan yang melekat pada program tersebut. Permasalahan muncul bisa karena isi program kurang sesuai, manajemen tidak tepat, kerjasama antar lembaga lemah, partisipasi warga komunitas kurang, atau masalah lainnya. Oleh sebab itu, perumusan masalah harus sempurna dan fokus agar rekomendasi dapat dibangun secara tepat dan mudah diimplementasikan.

Guna melengkapi rekomendasi detil seperti di atas, dapat dibuat rekomendasi umum mencakup saran-saran penting dan utama sifatnya yang perlu dilakukan, khususnya berkenaan dengan keadaan internal korporasi untuk menyempurnakan program CSR dan CD mereka. Berhasil-gagalnya program CSR dan CD ditentukan oleh banyak faktor, bisa karena faktor internal korporasi yang kurang serius dengan program ini, faktor eksternal pada institusi atau masyarakat penerima yang memiliki banyak masalah di dalamnya, atau faktor eksternal pemerintah yang tidak mendukung program tersebut. Khusus untuk korporasi, perbaikan terhadap kendala internal lebih mudah dilakukan daripada membenahi kendala eksternal. Oleh sebab itu, perbaikan dapat dimulai dari dalam korporasi dengan melihat kembali visi dan misi korporasi, apakah sudah mengakomodasi fungsi sosial korporasi. Lebih khusus lagi dapat dilihat kembali kebijakan, organisasi, program dan strategi, budget serta komunikasi antar bagian dalam korporasi, apakah sudah memadai untuk pengembangan program CSR dan CD menyikapi tantangan bisnis yang semakin kompleks (Ife, 1995; Ife and Tesoriero, 2003). Dilihat dari visi dan misi sebagian besar korporasi tambang dan migas sudah mulai merubah cara pandang terhadap pemangku kepentingan sosial mereka. Namun implementasi visi dan misi pada tahap kebijakan, organisasi dan budget kerap masih banyak 
Tabel 8. Contoh Masalah dan Rekomendasi

\begin{tabular}{cll}
\hline Program & \multicolumn{1}{c}{ Masalah } & \multicolumn{1}{c}{ Rekomendasi } \\
\hline Pembangunan Jalan & 1) pembangunan belum selesai; & 1) Korporasi perlu kerjasama lebih formal dan terstruktur dengan \\
& 2) kualitas jalan dinilai buruk; & Pemda dan masyarakat agar sumberdaya dapat disatukan dan \\
3) kontrol terhadap kontraktor lemah. & $\begin{array}{l}\text { penyelesaian pembangunan dapat dipercepat; 2) Menetapkan standar } \\
\text { kualitas jalan yang ingin dibangun; 3) melakukan kontrol secara } \\
\text { berkala terhadap pekerjaan yang dilakukan oleh kontraktor. }\end{array}$
\end{tabular}

Pembangunan Prasarana Air Bersih

\author{
1) keterlibatan masyarakat kurang; \\ 2) Pembangunan tidak diarahkan \\ kepada pencarian sumber air \\ baru yang lebih baik.
}

1) Meningkatkan partisipasi masyarakat dalam proses pembangunan, misalnya membentuk organisasi dan sistem pengelolaan air bersih berbasis masyarakat; 2) Bekerjasama dengan Pemda dalam mengusahakan sumber air baru dan menambah sumber air yang telah ada. kekurangannya. Untuk itu perbaikan internal secara serius perlu dilakukan guna menunjang program CSR dan CD yang semakin signifikan perannya. Memang peran aktor (CEO) dan senior manajer sangat penting, berdasar pengalaman, program CSR dan CD lebih dominan ditentukan oleh cara pandang aktor daripada visi dan misi korporasi.

\section{Simpulan}

Seperti telah disinggung di depan, program CSR dan CD memiliki fungsi penting tidak hanya bagi korporasi melainkan bagi pemangku kepentingan mereka. Jika hasil evaluasi menunjukkan bahwa kinerja program CSR dan CD sebuah korporasi sangat baik maka hasil ini akan meningkatkan posisi korporasi terhadap pemangku kepentingan mereka (Gauthier, 2005). Setidaknya terdapat tiga aspek penting terkait dengan hasil evaluasi program CSR dan CD yang baik, yakni pertama, berkenaan dengan business performance; kedua, berkenaan dengan social legitimacy; dan ketiga, legal compliance. Ketiga aspek ini sangat penting bagi keberhasilan baik korporasi secara khusus maupun industri tambang dan migas secara umum. Dalam aspek kinerja bisnis terdapat dua hal penting, yakni corporate social performance, kinerja yang berkait-erat dengan perilaku korporasi terhadap pemangku kepentingan sosial seperti terhadap komunitas lokal dan masyarakat umum, namun penting bagi pemangku kepentingan bisnis mereka. Semakin baik kinerja CSR dan CD maka akan meningkatkan social performance korporasi tersebut sehingga akan semakin baik pula corporate image, baik terhadap konsumen maupun terhadap investor. Khususnya bagi konsumen, kesadaran konsumen atas perilaku korporasi terhadap pelanggaran hak asasi manusia, dampak lingkungan, korupsi atau secara umum good governance akhir-akhir ini semakin tinggi. Pelanggaran terhadap hal-hal tersebut dapat mengakibatkan boikot produk, sebagaimana pernah dialami oleh perusahaan minyak Shell pada konsumen di Eropa atas kasus pelanggaran HAM di Ogoni, Nigeria. Bagi investor, kinerja sosial akan menambah dan menarik minat karena dapat menjamin investasi mereka, bahwa investasi mereka secara sosial aman dari pelanggaran hukum dan etika, serta bebas dari tekanan publik. Oleh sebab itu, secara bisnis hasil program CSR dan CD dapat bermanfaat untuk memperkecil resiko politik bisnis bersangkutan.

Secara sosial, program CSR dan CD yang berhasil akan meningkatkan "social legitimacy" atau "keabsahan sosial” atas keberadaan dan operasi korporasi di lingkungan sosial tertentu, khususnya komunitas lokal. Legitimasi sosial berkenaan dengan bagaimana warga komunitas dalam lingkungan operasi tambang dan migas menerima kehadiran dan kegiatan eksploitasi sumber alam. Hal ini memang terkait dengan bagaimana manfaat ekonomi kegiatan dan hasil tambang, apakah menguntungkan warga setempat atau sebaliknya. Salah satu upaya meningkatkan manfaat ekonomi dapat dilakukan melalui program CSR dan CD. Oleh sebab itu kinerja CSR dan CD merukapan media penting untuk meningkatkan relasi korporasi dengan komunitas lokal, sekaligus sebagai strategi bagaimana membangun relasi korporasi dengan komunitas secara saling mendukung. Dari sejumlah penelitian penulis, terungkap bahwa terdapat kecederungan positif bahwa "semakin besar dana dan organisasi untuk program CSR dan CD maka semakin menurun kasus-kasus konflik antara korporasi dengan komunitas lokal” (Dody Prayogo, 2008b). Artinya, dapat diterjemahkan bahwa semakin baik kinerja program CSR dan CD maka semakin baik legitimasi sosial korporasi bersangkutan di hadapan komunitas lokal.

Dari aspek legal, pelaksanaan program CSR di Indonesia khususnya akan menunjukkan sebuah "kepatuhan hukum" serta memenuhi "tuntutan publik" bagi terciptanya good corporate governance secara global. Khususnya di Indonesia, salah satu pasal dalam UU pendirian perseroan yang baru mengharuskan korporasi melaksanakan program CSR sebagai salah satu bagian dari kegiatan korporasi (UU No. 40, 2007, tentang Perseroan Terbatas). Dengan dasar legal ini maka pelaksanaan CSR menjadi salah satu prasyarat memenuhi "legal compliance" korporasi untuk seluruh 
industri. Walaupun sempat kontroversial dan ditolak oleh sebagian kalangan, UU ini telah disahkan dan berarti kewajiban korporasi untuk melaksanakan program CSR sudah berjalan. Lebih luas lagi, ISO 26000 dalam waktu dekat akan segera disepakati dan secara bersama dan menjadi acuan dalam praktek CSR secara global. Oleh karenanya tekanan legal, baik secara nasional maupun global, mengharuskan korporasi untuk melaksanakan CSR. Kinerja pelaksanaan CSR akan menunjukan tinggi-rendahnya "legal compliance" korporasi terhadap aturan dan etika dalam menjalankan bisnis. Lebih jauh lagi, tinggi-rendahnya "legal compliance" akan menentukan baik-buruknya sikap dan tindakan negara dan publik terhadap korporasi serta produk yang dihasilkannya (Prayogo, 2010). Dengan dasar pertimbangan ini maka kinerja program CSR dan CD memiliki implikasi sangat penting dan luas baik terhadap korporasi, negara maupun masyarakat.

\section{Daftar Acuan}

Botes, L. \& van Rensburg, D (January 2000). Community participation in development: nine plagues and twelve commandments. Community Development Journal, 35 (1), 41-58.

Buchholtz, A.K., Allen C.A., Matthew A.R. (1999). Beyond Resources: The mediating effect of top management discretion and values on corporate philanthropy. Business and Society, 38 (2), 167-187.

CSRM (2005). Developing a community impacts monitoring and management strategy: A guidance document for Australian Coal Mining Operation. Brisbane: University of Queensland.

CSRM (2007). Assessing and managing the socioeconomic impacts of projects, A review of current mining industry practice. Brisbane: University of Queensland.

Cresswell, J.C. (1997) Research design, qualitative and quantitative approach. London: Sage Publications.

Dale, R. (2004). Evaluating development programs and projects. London: Sage Publications.

Davis, G. (2002). Scenarios: Exploring societal problems, Paper was presented at IUCN Futures Dialogues, Johanesburg, South Africa.

Denzin, N.K., \& Yvonna S.L. (2000). Handbook of qualitative research (2nd ed.). London: Sage Publications.

Denscombe, M. (2003), The good research guide for small scale social research project. Wiscounsin: Open University Press.
Gauthier, C. (2005). Measuring corporate social and environmental performance: The extended life-cycle assessment. Journal of Business Ethics, 59, 199-206.

Griffin, J.J. (2000). Corporate social performance: Research direction for $21^{\text {st }}$ century. Business and Society, 39 (4), 479-491.

Gunn, C., \& Hazel, DG. (1991). Reclaiming capital, democratic initiatives and community development. Ithaca: University Press.Cornell

Hennigfeld, J., Manfred, P., \& Nick, T. (2006). The ICCA handbook on corporate social responsibility. West Sussex: John Wiley and Sons.

Ife, J. (1995). Community development, creating alternatives, vision, analysis and practice. Melbourne: Longman.

Ife, J., \& Frank, T. (2003). Community development, alternatif pengembangan masyarakat di era globalisasi (3rd ed.). Yogyakarta: Pustaka Pelajar.

ISO 26000 (2007), Working Draft 4.1, ISO/TMB/WGSR IDTF N050.

King, J.A., Lynn, L,M., \& Carol, T.F. (1987). How to assess program implementation. London: Sage Publication.

Mahon, J.F. (2002). Corporate reputation, A research agenda using strategy and stakeholder literature. Business and Society, 41 (4), 415-445.

Maignan, I., \& O.C. Ferrell (2004). Corporate social responsibility and marketing: An integrative approach. Journal of Academy of Marketing Science, 32 (1), 3-19.

Murray, J. (2004). Corporate social responsibility discussion paper. Global Social Policy, 4 (2), 171-195.

Neuman, W.L. (1994). Social research methods, qualitative and quantitative approaches. New York: Allyn \& Bacon.

Orlitzky, M., \& John D.B. (2001). Corporate social performance and firm risk: A meta-analytic review. Business and Society, 40 (4), 369-396.

Patton, M.Q. (1990). Qualitative evaluation and research methods. London: Sage Publication.

Prayogo, D., et al. (2007). Evaluasi program community development Conoco Phillips, Kecamatan Palmatak dan Terempa, Kabupaten Natuna, Kepulauan Riau”, Laporan Penelitian, Depok: LabSosio UI.

Prayogo, D., et al. (2008a), "Evaluasi komprehensif program community development Premier Oil, 
Kabupaten Natuna, Kepulauan Riau,” Laporan Penelitian, Depok: LabSosio UI.

Prayogo, D., et al. 2008b), Konflik antara Korporasi dengan komunitas lokal, Sebuah kasus empirik pada industri geotermal di Jawa Barat, Depok: FISIP UI Press.

Prayogo, D., et al. (2008c), “Corporate cocial responsibility, social justice dan distributive welfare dalam industri tambang dan migas di Indonesia," Galang, Vol. 3 No. 3, 57-74.

Prayogo, D., et al. (2010). Anatomi konflik antara korporasi dengan komunitas lokal pada industri geotermal di Jawa Barat. Makara seri Sosial Humaniora, 14 (1), 25-34

Prayogo, D., et al. (2010) "Studi Evaluasi dan Rencana Pengembangan Program Community Development Industri Tambang Granit, Kabupaten Karimun, Kepulauan Riau”, Laporan Penelitian, Depok: LabSosio UI.
Sharma, S., Amy L.P., \& Vredenburg, H. (1999). Corporate environmental responsiveness strategies, the importance of issue interpretation and organizational context. The Journal of Applied Behavioral Science, 35 (1), 87-108.

Stone, B.A. (2001). Corporate social responsibility and institutional investment. Business and Society, 40 (1), 112-117.

Undang-Undang No. 40 (2007), tentang Perseroan Terbatas.

Wartick, S.L., (2002). Measuring corporate reputation, definition and data. Business and Society, 41 (4), 371392.

Warhurst, A. (2001). Corporate citizenship and corporate social investment, drivers of tri-sector partnership. JCC.

Yakoveleva, N. (2005), Corporate social responsibility in the mining industries. London: Ashgat. 